\title{
Practical Application Analysis of Video Teaching Mode in Computer Teaching in Colleges and Universities
}

\author{
Xianping Wang \\ School of Software Engineering \\ Chongqing University of Arts and Sciences \\ Chongqing, China
}

\begin{abstract}
The use of video teaching resources in multimedia has greatly improved the efficiency of computer teaching. It is in a mutually reinforcing relationship with the development of computers. The increase in students' learning interest has also contributed to the development of video teaching models. Starting from the connotation and classification of video teaching, this article mainly analyzes the characteristics and influence of video teaching resources. At the same time, specific solutions are proposed for the problems in video teaching.
\end{abstract}

Keywords-video teaching mode; video teaching plan; assisted instruction

\section{INTRODUCTION}

Computer information processing technology has become the forerunner of the information society. The speed of computer science development is changing with each passing day. At present, the computer education in colleges and universities should be improved to cultivate students' interest and stimulate self-improvement. In order to achieve this teaching purpose, video teaching mode is one of the effective methods. Therefore, it has important practical significance for improving computer teaching methods.

\section{THE CONNOTATION AND TYPE OF VIDEO TEACHING RESOURCES}

According to the video persistence principle, when the image changes are more than 24 frames, the human eye cannot distinguish a single picture. Throughout the visual, the picture is smooth and continuous. And the continuous picture is called video. The development of information technology and the recorded segments of video, existing in the form of streaming media, can be played simultaneously when received by computers. Video resources are important modern curriculum resources. The video resources in computer teaching are used in students' learning. It can assist teachers' teaching, including graphics, text, animation and sound, etc.. It is a kind of dynamic image data. Computer video teaching has changed the transmittal mode of the teaching content, and has undergone fundamental changes. Students can intuitively understand it. And it would increase their interest in learning. In video teaching, the main role of students can be fully utilized.

According to different sources, video resources are divided into three types of video resources: self-recording production resource, download network resources, and commercial purchasing resources. There are many downloads on the Internet, and the main contents include the classroom teaching video resources of famous teachers, and the teaching materials of subject experts [1]. There are four main types of commercial purchases. The first is a video for teaching. The current mainstream is MOOC resources. Its main features are scientific. However, it is short and refined. And it can directly be applied to the classroom. Second is the CD-ROM for teaching assistants. It is generally published by publishing houses. Its main feature is its lack of interest but its strong knowledge. For example, the CD-ROM comes with the textbook. The third is education software and resource repository system. It mainly contains teaching materials such as audio, video, language, animation, etc. The purpose is to produce for teaching and research. The last one is a CD recording made by a person. There are excellent courses, high-quality classes, class teaching competitions, and courseware production, as well as special video materials recorded by professional. No matter what kind of video data, it can provide assistance and reference for teachers' teaching.

\section{CHARACTERISTICS OF VIDEO TEACHING RESOURCES}

Video resources bring new vigor to computer teaching. Many teachers feel that the use of video resources in computers has unparalleled advantages in specific teaching experiments. It is mainly manifested in the following aspects:

\section{A. Excellent Pictures and Texts, Good Image Perception}

Video resources, integrating images, sounds and texts, give people a strong visual impact and leave a deep impression on the students' minds. In computer teaching, the unique charm is induced to guide students' multiple senses. As a result, the boring teaching process became vivid and lively. At the same time, it also deepens the understanding of students' knowledge [2]. It is suitable for personalized 
learning. Also, it mobilizes the initiative of students. In teaching, teachers use video resources to teach students with emotional emotions. Students are more likely to enter their roles. The spread of knowledge is more stereoscopic. In the context of acoustic image and language, students' psychology is easy to enter in the best state.

\section{B. Large Content of Teaching Information}

In the information age today, with the use of video resources, students have a lot of access to information, which helps shorten teaching time and improve teaching efficiency. Video resources, which cover the teaching content of software and hardware, originate from the operation of realworld computer software and hardware. The students can easily accept a lot of computer knowledge through this method. In a relatively short period of time, they can effectively acquire more knowledge.

\section{Accessing to Teaching Resources Easily}

The 21st century is an information age and an era of resource sharing. Video resources are no exception. It can achieve short-range sharing through local area network. Also, it can achieve remote sharing through the Internet. The acquisition of computer teaching video resources mainly includes video of audiovisual bookstore, online download videos, and teacher-produced video courseware. The teachers' video is a video created for the teaching material content. At the same time, teachers collect related videos and present electronic courseware in vivid forms [3]. With interactive video courseware, students can have learning and training. And then, they can consolidate teaching content. With video resources, the students can have the watching in many times without limitations of time and space through terminal devices of multimedia communication network such as mobile device PDA or mobile phones.

\section{THE IMPACT OF VIDEO TEACHING ModE}

The video teaching mode subverts the traditional teaching mode and has a profound impact on computer teaching in colleges and universities. Video teaching resources have caused changes in teaching models and teaching methods in colleges and universities. In terms of teaching contents and concepts, students determine their teaching content according to their own characteristics. And their learning time and learning content have greater freedom. The impact of video teaching resources is mainly manifested in the following aspects.

\section{A. The Reform of Teaching Forms}

In the traditional computer teaching, the main position of the teacher is emphasized. And it would develop the teaching with the teacher as the focus, and ignore the role of the student. During the teaching process, multimedia software is used to demonstrate and explain the teaching content. Most professional technical courses in most colleges and universities use "combination of explaining and practicing". However, students can only conduct experiments after a teacher puts out a knowledge point. Various teaching reforms of the Ministry of Education require students to be the center. However, in the teaching process, due to the large number of students and the large amount of teaching tasks that must be completed in accordance with the teaching plan, it is still the mainstream of teaching to fill in the teaching contents of the teaching materials. . In addition, due to the differences in college equipment, college teachers and students' computer levels, it has increased the teaching difficulty to different degrees. It is difficult for teachers to teach students in accordance with their own characteristics [4]. Video teaching mode emerged with multimedia technology and computer network technology. Textual knowledge in teaching materials is processed through computer and recorded into MOOC video teaching resources. And it was put into public platforms for students to download or learn online. As a result, the students raised questions in a targeted manner and enhanced the effectiveness in communicating with the teachers. Therefore, the teacher's energy can be transferred from the teaching material content. And there can be sufficient time for targeted explanations and answers to students' difficult problems. At the same time, it is possible to give full play to students' initiative and self-study and improve their ability to study independently.

\section{B. The Lack of Teachers Has Been Alleviated}

Higher education is professional education for students. Due to the different academic characteristics of each university and the different degrees of development of each school, it is difficult to train an excellent computer college teacher. At the same time, excellent teachers have scientific research tasks, which further increase the tension of teachers. In order to alleviate this problem, under the conditions of video teaching, excellent computer teachers record video teaching, and use departments with shortage of teachers [5]. In this way, the physical location and time are broken. As long as there is a computer, the teacher can conduct video teaching and improve teaching efficiency. And, it can make up for the shortage of resources for teachers in various schools.

\section{It is Conducive to Experimental Teaching Reform}

In computer teaching, computer experiment is an important part of experimental teaching. The traditional experimental teaching manual mainly depends on the operation method. However, it ignores precautions and interpretation of errors in the experiment. During the recording of the video teaching manual, a lot of video information is used to explain the need for attention in the experiment. Multimedia teaching is not limited by time and space. Students are the main body of learning. Using video teaching methods, students can master practical skills by repeatedly watching video files and practicing for many times. Taking the author's teaching as an example. The author would record the practice content as a video before each lecture. And the author would focus on detailed explanations of key points. When the students are in class, the videos are distributed to each student, and the students can watch while operating. Therefore, students quickly 
master the practical content and achieve the teaching goals with high efficiency.

\section{THE PROBLEM OF VIDEO TEACHING}

\section{A. The Popularity of Video Teaching Mode Is Narrow}

On the whole, not all computer teachers use video teaching. The main reason is the influence of traditional ideas. Some teachers are skeptical of video resources and insist on using traditional teaching methods. There are also some teachers who are unfamiliar with modern educational technology. And it restricts the popularity of video resources. On the other hand, some universities have good teaching conditions. However, there is no public video resource server. Students cannot use it at any time. At the same time, students' passive utilization is also the important reason. According to the survey, some colleges and universities use less than $50 \%$ of equipment. The main reason is that video teaching is not the focus of work and has not been taken seriously. There is also room for improvement in students' habitual cultivation of video resources.

\section{B. Contradiction Between Video Teaching and Teaching Students According to Their Aptitude}

The method factor is the core that affects the application of video resources. The teachers would use video case teaching in computer video teaching. Most teachers believe that students like to use video and also understand videos. In fact, this concept is somewhat biased. Some students have a strong sense of comprehension. However, some students have poor awareness and comprehension. Therefore, even if the students watched the video, they did not understand the knowledge. When the students go to practice, they cannot complete the learning tasks as required. This shows that some students need to be taught in accordance with their aptitude. And they can't use video teaching methods. The students need to complete the task under the guidance of teachers.

\section{The Lack of Effective Development of Video Resources}

In actual teaching, teachers download materials from the Internet, and a few teachers conduct video recording. The video courseware has a large workload and high technical requirements. However, some schools do not have these conditions, which limit the development of video resources to a certain extent. Even in teachers' self-development, there are cases where video recording is not ideal. Teachers need to plan video recordings, record clips, etc. Therefore, many teachers are can't make the download through online resources, which limits the development of video resources to a certain extent.

\section{APPliCATION STRATEGIES OF VIDEO TEACHING MODE}

\section{A. Formulating Relevant Document Requirements for Video Teaching}

One of the important aspects of teaching activities is the production of video teaching documents. On the basis of the production of teaching documents, the knowledge in the literal form realizes the transformation of video teaching documents. With a higher form of lesson preparation, the preparation of the teaching plan in the traditional teaching is realized. In the process of video preparation, the teachers need to improve the quality of the lesson preparation. It plays a key role in student interest and teaching effectiveness. The video teaching files what we are talking about include text, sound, pictures, etc.. Different elements have different forms of presentation. The teachers should effectively organize, coordinate, and present these element materials in the teaching documents. The students can improve learning efficiency in video teaching. This requires that the teachers should first master a video file production tool. There are software such as, screen recording experts and ulead video studio. In this process, teachers should prepare the text content, organize various resources, and collect relevant materials. And then, the teachers can use tool software, make orderly integration and complete the teaching work. Second, video education should reflect the learning process. Learning, discussion, practice, and review are four teaching steps. Reasonable scientific arrangement of time is the basis for completing video preparation. In the video preparation process, students' learning needs to be considered. Students focus on their studies to avoid losing attention and learning fatigue, resulting in reduced learning outcomes. Once again, when the teacher is explaining, he must be emotional. It is suitable for different students' listening requirements and achieves clear rhythm in language expression [6]. Finally, when organizing the content of the teaching, the teachers should pay attention to the level. There are special annotations on key knowledge points. Key annotations can also be achieved with different color fonts. Different teaching situations need to use different music. The students can remember clearly under different sensory stimulation. In the video preparation lesson, the teacher must consider the issue of students' differences. The basic and additional sections are for most students. The elective sections are for those students who have time for additional learning.

\section{B. Changing Teachers' Role in Video Teaching}

As we are in the Internet age, the spread of information has become diversified. In terms of knowledge acquisition, it has achieved faster access. In this transition, the teacher is not the only one who masters knowledge. And the owner of knowledge increases. In society, the measurement standards of talents have also changed. The amount of knowledge owned by talent is not unique. Unlike before, learning and innovation capabilities have become the standard for measuring talent. Under the conditions of this era, the teaching role of teachers needs to be transformed to adapt to the application of video teaching in computer teaching. There are mainly the following aspects in the transformation 
of the role of teachers in the video teaching mode. First of all, it is necessary to put aside the script. After a thorough understanding of the teaching, the teachers process the book knowledge and turn it into video teaching material. The purpose is to make it easier for the students to understand. In the collection and processing of knowledge information, and preparation of lesson plans, the importance of the preparatory work is self-evident. The student's interest in subsequent learning is directly affected. Second, in the video teaching mode, there are learning, discussion and other aspects. The design of lesson plans should be based on the progress of learning and effective control. To inspire students' interest should be continued. Then, students would follow the teacher. In teaching scheduling, the teacher becomes a leader. Once again, the teacher has the transformation in position. In traditional teaching, teachers need to make the explanation on the podium for a long time. However, after adopting video teaching, the main teaching problem for teachers is to deepen the practice of student learning and understand the progress of student learning. On the one hand, the teacher should help difficult students and guide them in their studies. At the same time, they should solve the problems encountered. The students truly become the subjects.

\section{CONCLUSION}

Video teaching plays an important role in improving computer teaching in colleges and universities. Each teacher adopts different ways and methods in the teaching. The application of video teaching mode, especially the MOOC teaching in recent years, undoubtedly enriches computer teaching in terms of teaching means and receives twice the result with half the effort. In order to promote teaching reform and the quality of computer teaching in colleges and universities, it will contribute an important force.

\section{REFERENCES}

[1] Ran Longchun, Wu Wentie. Research on the Application of Multimedia Technology in Distance Education [J]. Management and Technology Journal of SME. 2009 (02) 手龙春, 吴文铁. 多媒体技术 在远程教育中的应用研究[J]. 中小企业管理与科技刊. 2009(02)

[2] Zheng Xinrong, Bu Wei. Learning to seek knowledge. Beijing: Beijing Publishing House, 2006 郑新蓉, 卜卫.学会求知[M]. 北京: 北 京出版社,2006

[3] Merrill Hamming. Teaching Revolution. Beijing: China Aerospace Press, 2002 梅里尔.哈明.教学的革命[M]. 北京: 中国宇航出版社, 2002

[4] Wang Xiuying. The Application of Film and Television Resources in the Teaching of History in High School [D]. Changchun: Northeast Normal University, 2010 王秀英. 影视资源在高中历史教学中的应 用[D].长春: 东北师范大学, 2010

[5] Zhou Lingling. Research on Development and Utilization of Geovideo Resources in High Schools [D]. Changchun: Changchun Normal University, 2012 周玲玲. 高中地理视频资源开发利用研究 [D].长春:长春师范学院,2012

[6] Yang Mei. Application of Video Resources in Computer Courses [J]. Computer and Network, 2013 杨梅.视频资源在计算机课程中的应 用探讨[J].计算机与网络, 2013 